\title{
Process Optimization for Endoglucanase Production by in Submerged Fermentation
}

\section{Batık Kültür Fermentasyonunda Trichoderma Harzianum'dan Endoglukanaz Üretimi için En Uygun Süreçler}

\author{
Research Article
}

\author{
Muhammad Irfan 1,2*, Umar Asghar², Muhammad Nadeem², Hafiz Abdullah Shakir ${ }^{3}$, Javed Iqbal \\ Qazi $^{3}$, Rubina Nelofer ${ }^{4}$, Quratulain Syed ${ }^{2}$ \\ 'Department of Zoology, University of the Punjab New Campus, Lahore, Pakistan. \\ ${ }^{2}$ Food \& Biotechnology Research Centre (FBRC), Pakistan Council of Scientific and Industrial Research (PCSIR) Laboratories \\ Complex, Ferozepure Road, Lahore, Pakistan. \\ ${ }^{3}$ Department of Zoology, University of the Punjab New Campus, Lahore, Pakistan. \\ ${ }^{4}$ Food \& Biotechnology Research Center, PCSIR Labs Complex, Ferozpure Road, Lahore Pakistan.
}

\section{A B S T R AC T}

\begin{abstract}
n this study, endoglucanase was produced from Trichoderma harzianum in submerged fermentation using sugarcane as a substrate. For enhanced enzyme production, various parameters were optimized by one factor at a time approach. Maximum enzyme yield was obtained with initial medium pH of 4.0 , inoculum size of $2 \%$, sugarcane bagasse concentration of $2 \%$ and incubation temperature of $30^{\circ} \mathrm{C}$ for $72 \mathrm{~h}$ of fermentation period. Addition of tween-80 (0.2\%) to the fermentation medium had significant impact on endoglucanase production. Further supplementation of glucose and $\mathrm{NaNO}_{3}$ as synthetic carbon and nitrogen source favoured enzyme production respectively. Results of this study are very helpful in large scale enzyme production.
\end{abstract}

Key Words

Endoglucanase; T. harzianum; bagasse; submerge fermentation.

\section{ÖZET}

Bu çalışmada, substrat olarak şeker kamışı kullanılarak batık kültür fermentasyonuyla Trichoderma harzianum'dan endoglukanaz üretildi. Enzim üretimini iyileştirmek için belirli bir zaman aralığında çeşitli parametreler optimize edildi. Ortamın başlangıç $\mathrm{pH}^{\prime}$ । 4.0, aşılama miktarı \%2, şeker kamışı küspesi derişimi \%2 ve inkübasyon sıcaklığı $30^{\circ} \mathrm{C}$ de ve 72 saatlik fermentasyon süresiyle optimum enzim verimi elde edildi. Fermentasyon ortamına tween-80 (\%0.2) ilavesi endoglukanaz üretimini ciddi miktarda etkilemektedir. Buna ilave olarak sentetik karbon ve azot kaynağı olarak sırasıyla $\mathrm{NaNO}_{3}$ ve glikoz desteği, enzim üretimine katkı vermiştir. Çalışmanın sonuçları büyük ölçekli enzim üretimi için çok yararlıdır.

\section{Anahtar Kelimeler}

Endoglukanaz; T. harzianum; küspe; batık kültür fermentasyonu.

Article History: Received: Jan 14, 2016; Revised: Mar 14, 2016; Accepted: Mar 20, 2016; Available Online: Apr 01, 2016.

DOI: $10.15671 /$ HJBC.20164417569

Correspondence to: M. Irfan; Department of Zoology, University of the Punjab, New Campus, Lahore, Pakistan. 


\section{INTRODUCTION}

Cellulose is a natural renewable source on earth.

Cellulose has crystalline structure made up of long polymers of $\beta 1-4$, linked glucose units [1]. This crystalline structure is degraded by cellulase enzyme. These cellulases are divided into three main types based on their action; endoglucanase (endo-1, 4- $\beta$-D-glucanase, EG, EC 3.2.1.4); cellobiohydrolase or exoglucanase (exo-1, 4- $\beta$-Dglucanase, $\mathrm{CBH}, \mathrm{EC}$ 3.2.1.91) and $\beta$-glucosidase (1, 4- $\beta$-D-glucosidase, BG, EC 3.2.1.21) [2,3].

These cellulases are produced by a variety of microorganisms. Among all these microrganisms, fungi have been reported to produce cellulases include Sclerotium rolfsii, $P$. chrysosporium, Trichoderma, Aspergillus, Schizophyllum and Penicillium [4-6]. Trichoderma and Aspergillus has been most extensively studied fungal genera used for cellulase production [7].

Currently scientists are being more attraction in this research field due to its potential application. Cellulases are widely used in many industries like textile, biofuel, pulp and paper, detergent, starch processing and in fruit processing industry $[3,8]$. In this investigation, we reported production of endoglucanase from Trichoderma harzianum in submerged fermentation using sugarcane bagasse as substrate.

\section{MATERIALS AND METHODS}

\section{Microorganism}

Fungal strain of Trichoderma harzianum was obtained from Microbiology laboratory of Food \& Biotechnology Research Centre (FBRC), Pakistan Council of Scientific and Industrial Research (PCSIR) Laboratories complex, Ferozpur road Lahore, Pakistan. The strain was cultured and maintained on potato dextrose agar (PDA) slants and stored at $4^{\circ} \mathrm{C}$ for further use.

\section{Substrates}

Sugarcane bagasse was obtained from Shakargunj sugar mills Jhang Pakistan. The substrate was chopped to powder form (Approximately 2 $\mathrm{mm}$ ) and used for endoglucanase production in submerge fermentation.

\section{Preparation of Spore Suspension}

One week old cultures were used for the spore suspension preparations. Ten millilitres of sterile distilled water was pipette on to the culture plates. The suspension was thoroughly mixed with a sterile spreader until an even suspension of spores was obtained.

\section{Enzyme Production}

Self-designed media was used for production of endoglucanase by Trichoderma harzianum in submerged fermentation. Erlenmeyer flask of $250 \mathrm{ml}$ capacity containing $25 \mathrm{ml}$ of the media (glucose $0.5 \%, \mathrm{NaNO}_{3}$ 0.5\%, tween-80 0.4\%) with $2 \%$ substrates were sterilized at $121^{\circ} \mathrm{C}, 15 \mathrm{psi}$ for $15 \mathrm{~min}$. The media was allowed to cool after sterilization and inoculated with $2 \%$ of spore suspension and incubated at $30 \pm 1^{\circ} \mathrm{C}$ with the agitation speed of $120 \mathrm{rpm}$. After completion of the fermentation time, the culture filtrate was centrifuged at $8000 \mathrm{xg}$ for $10 \mathrm{~min}$ at $4^{\circ} \mathrm{C}$ to remove unwanted particles and spores. The clear supernatants obtained after centrifugation were used for the estimation of extracellular enzyme (endoglucanase).

\section{Analytical Methods}

Endoglucanase activity was estimated as described earlier [9]. Reaction mixture containing $500 \mu \mathrm{L}$ of the enzyme sample along with 500 $\mu \mathrm{L}$ of $1 \%(\mathrm{w} / \mathrm{v}) \mathrm{CMC}$ in $50 \mathrm{mM}$ citrate buffer $\mathrm{pH}$ 5 was incubated, in a water bath at $50^{\circ} \mathrm{C}$, for 30 min. After incubation $1.5 \mathrm{~mL}$ of DNS was added and boiled for 5 minutes and absorbance was taken spectrophotometrically at $550 \mathrm{~nm}$. The reducing ends liberated were then measured with DNS [10]. One unit (IU) of CMCase was defined as the amount of enzyme releasing 1 micromole of glucose per minute under the assays conditions.

\section{Optimization of Process Parameters}

Various process parameters such as fermentation time (24-120 h), initial medium $\mathrm{pH}$ (2-9), incubation temperature $\left(25-45^{\circ} \mathrm{C}\right)$, inoculum size $\left(0.5^{-}\right.$ $3.0 \% \mathrm{v} / \mathrm{v})$, substrate concentration $(1-5 \% \mathrm{w} / \mathrm{v})$, additional sugars $(0.5 \%$ of each glucose, fructose, maltose, sucrose, starch, xylose), nitrogen sources $(0.5 \%$ of each urea, peptone, yeast extract, $\left.\mathrm{NaNO}_{3}, \mathrm{NH}_{4} \mathrm{Cl},\left(\mathrm{NH}_{4}\right)_{2} \mathrm{SO}_{4}\right)$ and tween-80 concentration $(0.1-0.5 \%)$ were optimized for 


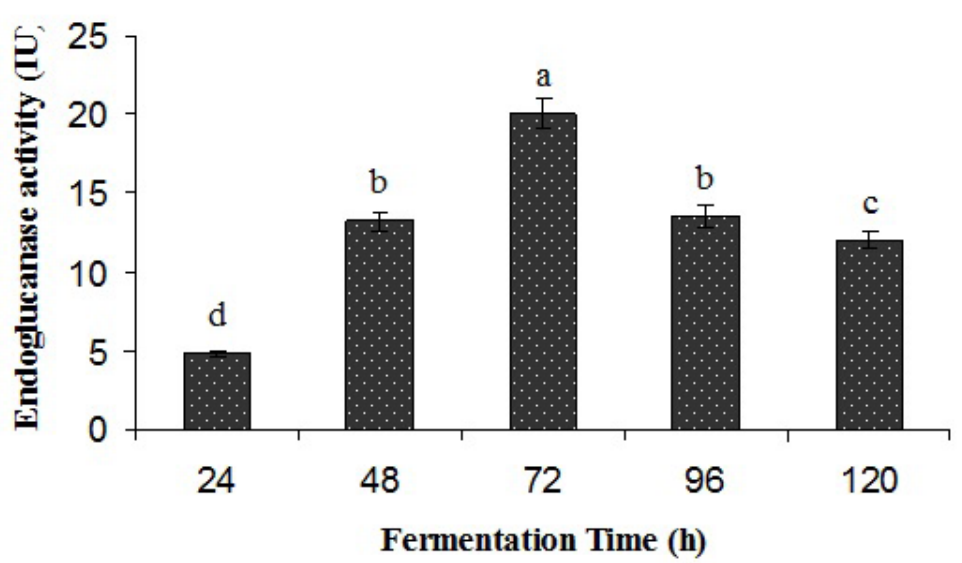

Figure 1. Time course production of endoglucanase by T. harzianum in submerge fermentation with agitation of $120 \mathrm{rpm}$. The error bars represent the standard deviation of the mean based on three replicates.

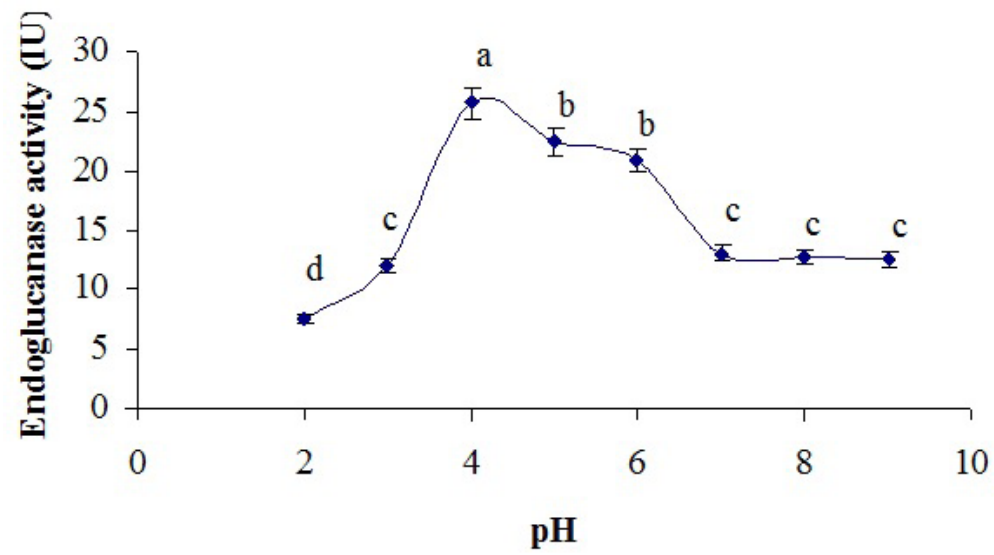

Figure 2. Effect of initial medium $\mathrm{pH}$ on endoglucanase production by $\mathrm{T}$. harzianum in submerge fermentation at $30^{\circ} \mathrm{C}$ with agitation of $120 \mathrm{rpm}$. The error bars represent the standard deviation of the mean based on three replicates.

endoglucanase production by Trichoderma harzianum in submerge fermentation.

\section{Statistical Analysis}

Data was statistically analyzed by ANOVA using Microsoft Excel program with $P<0.05$.

\section{RESULTS AND DISCUSSION}

\section{Time Course of Production}

Time course of fermentation was studied by incubating flasks for various time periods ranging from $24 \mathrm{~h}$ to $120 \mathrm{~h}$. Optimum time for endoglucanase production by $T$. harzianum was found $72 \mathrm{~h}$ (Figure 1). Further increased fermentation period resulted decline in enzyme production. Akinola et al [11] reported 6 days of fermentation period was best for endoglucanase production. Previous study suggested that fermentation period varies for cellulase production by $T$. harzianum using different carbon sources in fermentation medium [12]. Sharma et al [13] reported $112 \mathrm{~h}$ as optimized fermentation period for cellulase activity from $T$. harzianum and $T$. reesei.

\section{Effect of Initial Medium pH}

Initial medium $\mathrm{pH}$ is very important factor for growth of microorganism. Various $\mathrm{pH}$ ranges (29) were tested for maximum enzyme production. Results showed that initial medium $\mathrm{pH}$ of 4 was found best for maximum enzyme production. Increased initial medium $\mathrm{pH}$ leads decline in enzyme production (Figure 2). Results revealed that this fungus can grow in acidic environment. 


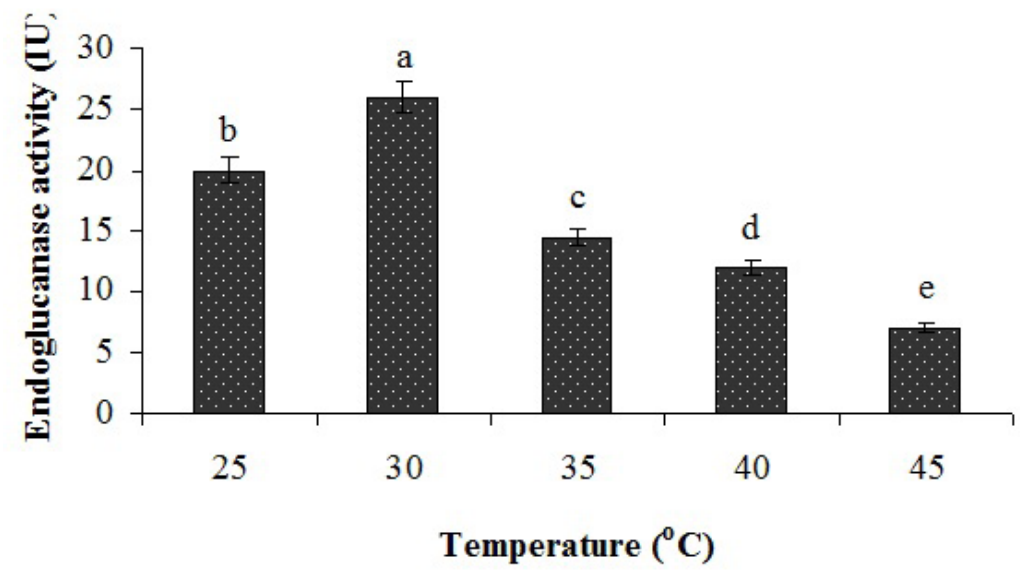

Figure 3. Effect of incubation temperature on endoglucanase production by T. harzianum in submerge fermentation with agitation of $120 \mathrm{rpm}$. The error bars represent the standard deviation of the mean based on three replicates.

Similar findings $(\mathrm{pH} 4)$ were also reported by Rubeena et al [14] and Kumar et al [15]. Other studies reported that initial medium $\mathrm{pH}$ of 6 is suitable for maximum cellulase production $[11,16]$.

\section{Effect of Incubation Temperature}

Temperature is also very important factor for growth of microorganisms. Different temperature ranges $\left(25-45^{\circ} \mathrm{C}\right)$ were applied for maximum enzyme production. Results showed (Figure 3) that incubation temperature of $30^{\circ} \mathrm{C}$ was found best for maximum endoglucanase production in submerge fermentation by T. harzianum. Findings of this study are in agreement with Kumar et al [15] which reported $30^{\circ} \mathrm{C}$ optimum temperature for endoglucanase production. Some strains of $T$. harzianum produced maximum endoglucanase at temperature $25^{\circ} \mathrm{C}$ [11] and $28^{\circ} \mathrm{C}$ [14]. Incubation temperature of $35^{\circ} \mathrm{C}$ was also reported for maximum cellulose production by $T$. harzianum and T. reesei [13].

\section{Effect of Inoculum Size}

Figure 4 described the effect of inoculum size on endoglucanase production in submerged fermentation. Results revealed that $2 \%$ inoculum size yielded maximum enzyme production in submerged fermentation. Low or high inoculum level resulted decreased enzyme production. Malik et al [17] reported $4 \%$ inoculum size for cellulase production by Trichoderma viride. Irfan et al [18] reported $3 \%$ inoculum level for CMCase production by $A$.niger in submerged fermentation. Highest inoculum size of $10 \% \mathrm{v} / \mathrm{v}$ was also reported for CMCase production by Aspergillus hortai in submerged fermentation [19].

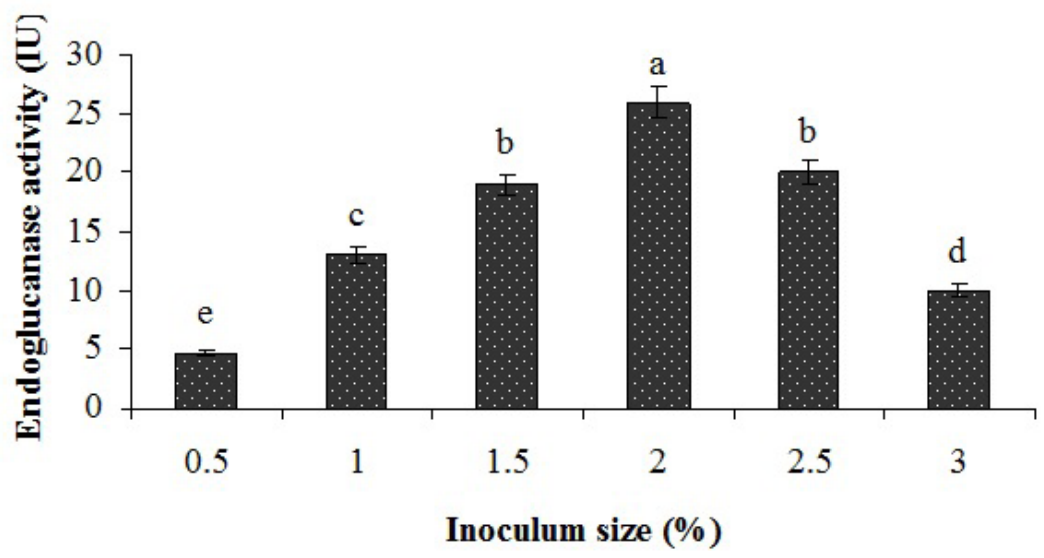

Figure 4. Effect of inoculum size on endoglucanase production by $T$. harzianum in submerge fermentation at $30^{\circ} \mathrm{C}$ with agitation of $120 \mathrm{rpm}$. The error bars represent the standard deviation of the mean based on three replicates. 


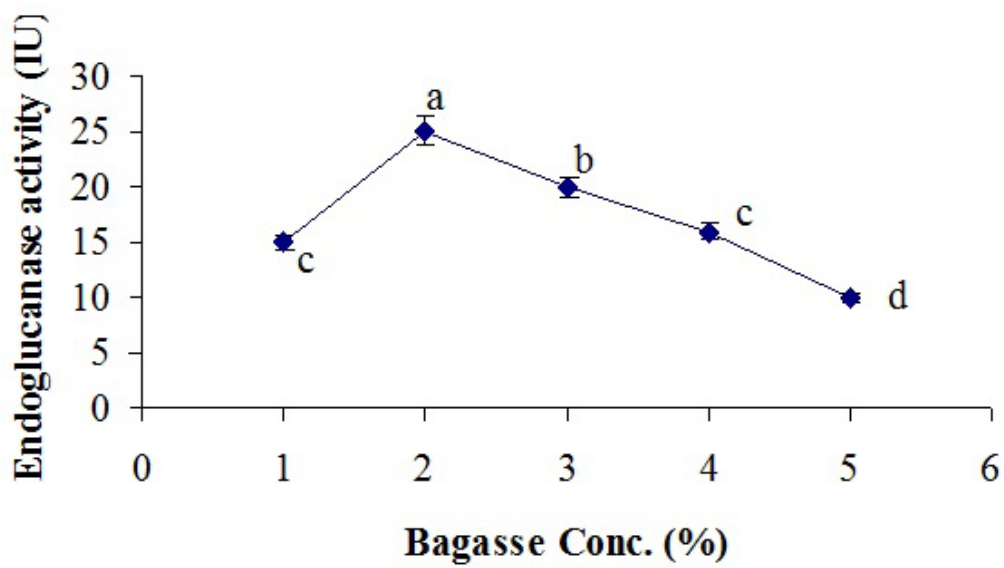

Figure 5. Effect of substrate (bagasse) concentration on endoglucanase production by T. harzianum in submerge fermentation at $30^{\circ} \mathrm{C}$ with agitation of $120 \mathrm{rpm}$. The error bars represent the standard deviation of the mean based on three replicates.

\section{Effect of Substrate Concentration}

Optimum concentration of substrate (bagasse) was investigated by varying concentration from $1-5 \%$ in submerged fermentation. Maximum enzyme production was achieved at $2 \%$ bagasse concentration (Figure 5). High concentration (5\%) of substrate leads to decreased enzyme production. In earlier reports $3 \%$ concentration of substrates (saw dust, corn cob and sugarcane bagasse) was optimum for enzyme production [20]. Irfan et al [21] reported 2\% substrate concentration for CMCase production.

\section{Effect of Sugars}

Various sugars as synthetic carbon source were employed for maximum enzyme production in submerged fermentation. Results revealed that supplementation of glucose in fermentation medium favoured maximum enzyme production (Figure 6). Other studies also suggested that glucose is best carbon source for endoglucanase production by $T$. harzianum in submerged fermentation [11,14].

\section{Effect of Nitrogen Source}

Figure 7 described the effect of various nitrogen sources on endoglucanase production by $T$. harzianum in submerged fermentation. Maximum enzyme production was achieved with $\mathrm{NaNO}_{3}$ as best nitrogen source. Similar findings were also reported by Rubeena et al [14]. Akinola et al [11] reported casein as a best nitrogen source for endoglucanase production by $T$. harzianum in submerged fermentation.

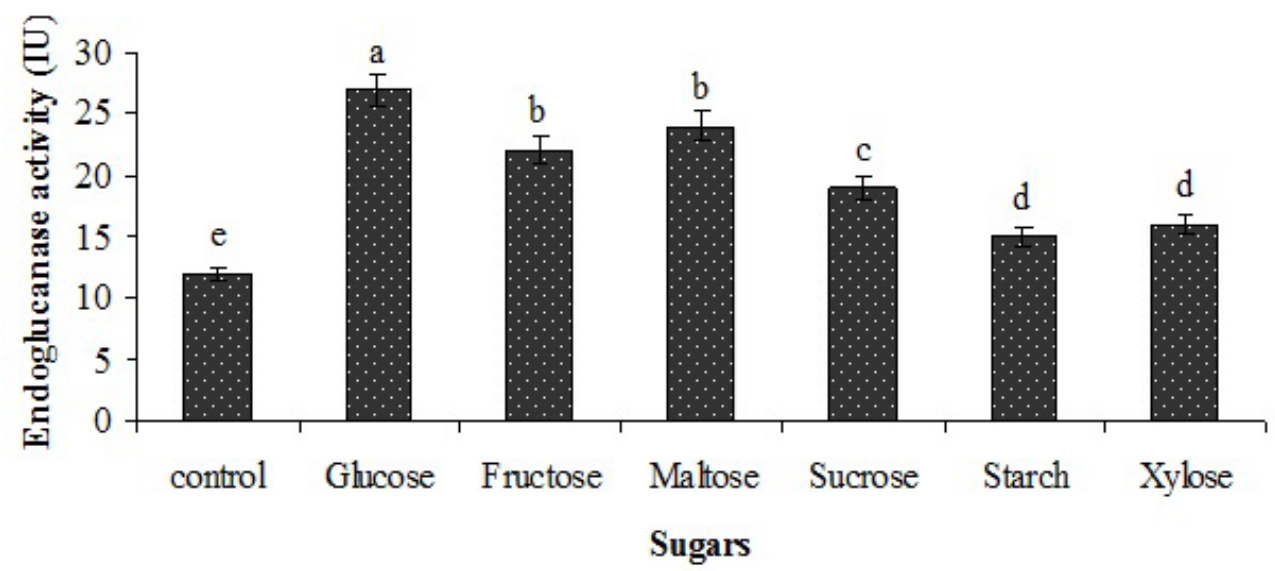

Figure 6. Effect of sugars on endoglucanase production by T. harzianum in submerge fermentation at $30^{\circ} \mathrm{C}$ with agitation of $120 \mathrm{rpm}$. The error bars represent the standard deviation of the mean based on three replicates 


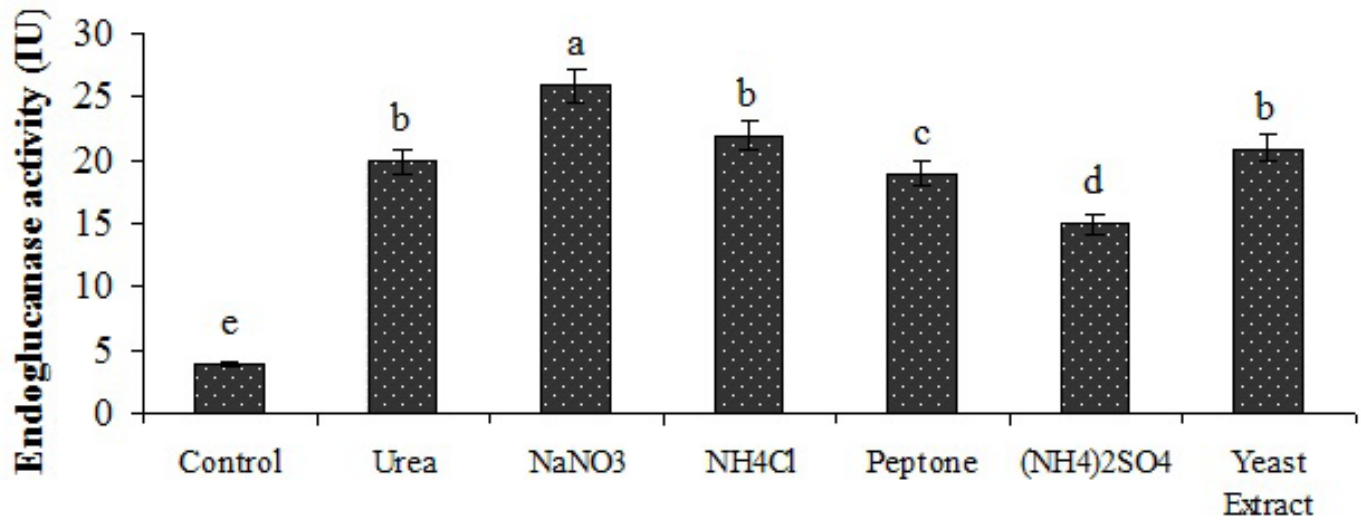

Nitrogen s ource

Figure 7. Effect of nitrogen sources on endoglucanase production by $T$. harzianum in submerge fermentation at $30^{\circ} \mathrm{C}$ with agitation of $120 \mathrm{rpm}$. The error bars represent the standard deviation of the mean based on three replicates.

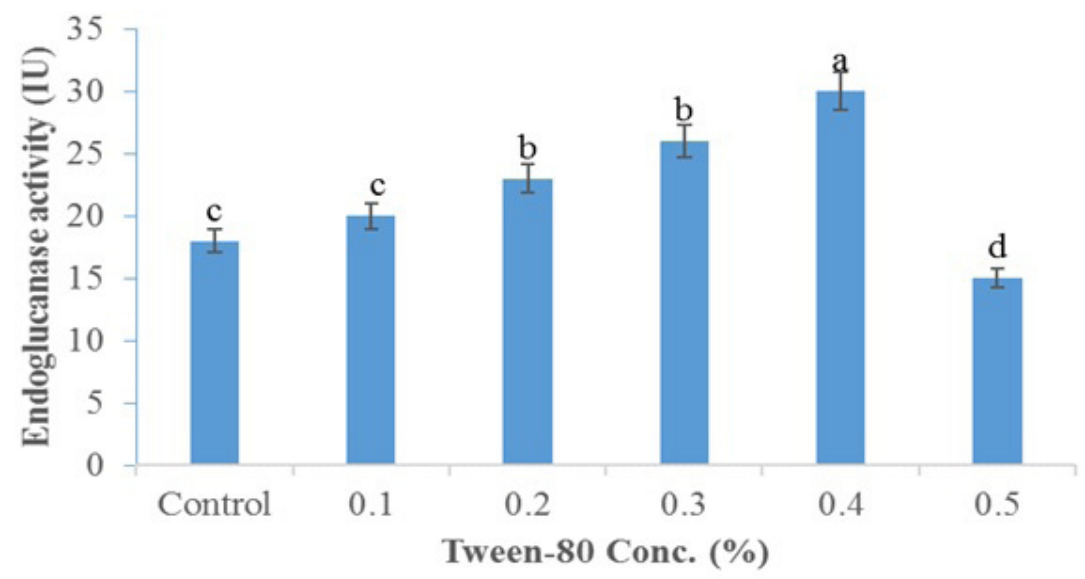

Figure 8. Effect of tween-80 on endoglucanase production by T. harzianum in submerge fermentation at $30^{\circ} \mathrm{C}$ with agitation of $120 \mathrm{rpm}$. The error bars represent the standard deviation of the mean based on three replicates.

\section{Effect of Tween-80}

Different concentrations (0.1-0.5\%) of tween-80 were applied to check the optimum production of endoglucanase by $T$. harzianum in submerged fermentation. Results (Figure 8 ) revealed that tween- 80 concentration of $0.4 \%$ yield maximum titter of endoglucanase production $(30.0 \pm 0.8 \mathrm{IU})$ in submerge fermentation. Enzyme production was increased up to $0.4 \%$ concentration, after that enzyme production was decreased with increased concentration of tween-80 (0.5\%). Similar findings were also reported $(0.4 \%$ tween-80) for cellulase production by Aspergillus terrus in submerge fermentation. Addition of tween-80 (surfactants) to the fermentation medium leads to increased permeability of the microbial membranes which ultimately affects the cost of enzyme production [22]. For cellulase and $\beta$-glucosidase production by mixed cultures of Aspergillus phoenicis and Trichoderma reesei, tween-80 concentration of $0.2 \%$ was found optimum [23].

\section{Conclusions}

Results of this study indicated that optimization of process parameters play an important role in improvement of enzyme production in submerged fermentation. The optimized conditions for endoglucanase production was substrate concentration of $2 \%$, glucose $0.5 \%, \mathrm{NaNO}_{3} 0.5 \%$, tween-80 $0.4 \%$, initial medium $\mathrm{pH}$ of 4 , inoculum size of $2 \%(\mathrm{v} / \mathrm{v})$ for $72 \mathrm{~h}$ of fermentation period at $30^{\circ} \mathrm{C}$. Enzyme produced in this process is very helpful particularly in second generation biofuels like bioethanol production from plant biomasses. 


\section{ACKNOWLEDGEMENTS}

Authors thanks to Ministry of Science and Technology (MoST), Islamabad Pakistan for financial support under the project "Production of Bioenergy from Plant Biomass."

\section{References}

1. D. Shallom, Y. Shoham. Microbial Hemicellulases. Curr. Opin. Microiol., 6 (2003) 219-228.

2. Y.H. Li, M. Ding, J. Wang, G.J. Xu, F. Zhao. A novel thermoacidophilic endoglucanase, Ba-EGA, from a new cellulose degrading bacterium, Bacillus sp. AC-1. Appl. Microbiol. Biotechnol., 70 (2006) 430-436.

3. J. Gao, H. Weng, D. Zhu, M. Yuan, F. Guan, Yu Xi. Production and characterization of cellulolytic enzymes from the thermoacidophilic fungal Aspergillus terreus M11 under solid-state cultivation of corn stover, Bioresour. Technol., 99 (2008) 7623-7629.

4. L.T. Fan, M.M. Gharpuray, Y.H. Lee. Cellulose Hydrolysis. Berlin, Germany Springer-Verlag, 3 (1987) 1-68.

5. D. Sternberg. Production of cellulase by Trichoderma, Biotechnol Bioeng Symp, (1976) 35-53.

6. S.J.B. Duff, W.D. Murray. Bioconversion of forest products industry waste cellulosics to fuel ethanol a review, Bioresour Technol, 55 (1996) 1-33.

7. Y. Sun, J. Cheng. Hydrolysis of lignocellulosic materials for ethanol production a review, Biores Technol., 83 (2002) 1-11.

8. J. Zhou, Y.H. Wang, J. Chu, Y.P. Zhuang, S.L. Zhang, P. Yin. Identification and purification of the main components of cellulases from a mutant strain of Trichoderma viride T 100-14, Bioresour. Technol., 99 (2008) 6826-6833.

9. M. Irfan, M. Nadeem, Q. Syed. Production of cellulases and hemicellulases from cellulolytic fungal cultures in submerged fermentation using agricultural wastes, Elect. J. Biol., 9 (2013) 62-66

10. G.L. Miller. Use of dinitrosalicylic acid reagent for determination of reducing sugars, Anal. Chem., 31 (1959) 426-428.

11. G.E. Akinola, O.T. Olonila, B.C. Adebayo-Tayo. Production of cellulases by Trichoderma species, Acad Arena, 4 (12) (2012) 27-37.

12. N. Aslam, M.A. Sheikh, M. Ashraf, A. Jamil. Exprression pattern of Trichoderma cellulases under different carbon sources, Pak J. Bot., 42 (2010) 2895-2902.
13. M. Sharma, S.S. Saju, S. Chandara, M. Srivastava, P. Sharma. Comparative evaluation of cellulase activity in Trichoderma harzianum and Trichoderma reesei, Afr. J. Microbiol. Res., 8 (2014) 1939-1947.

14. M. Rubeena, K. Neethu, S. Sajith, S. Sreedevi, P. Priji, K.N. Unni, M.K.S. Josh, V.N. Jisha, S. Pradeep, S. Benjamin. Lignocellulolytic activities of a novel strain of Trichoderma harzianum, Adv. Biosci. Biotechnol., 4 (2013) 214-221.

15. D. Kumar, M. Muthukumar, N. Garg. Utilization of Mahua cake for cellulase production by using Trichoderma harzianum NAIMCC-F-02957 under submerged fermentation, Acad. J. Plant. Sci., 5 (2012) 01-06.

16. T. Juhasz, N. Szengyel, N. Szijarto, K. Recezey. Effect of $\mathrm{pH}$ on cellulase production of Trichoderma reesei RUT C30, Biotechnology, 113 (2004) 201-212.

17. S.K. Malik, H. Mukhtar, A.A. Farooqi, I. Haq. Optimization of process parameters for the biosynthesis of cellulases by Trichoderma viride, Pak, J, Bot, 42 (2010) 42434251.

18. M. Irfan, U. Irfan, Z. Razaq, Q. Syed, M. Nadeem. Utilization of agricultural wastes as a substrate for carboxymethyl cellulase production from Aspergillus niger in submerged fermentation, Int. J. Agro. Vet. Med. Sci., 5 (2011) 464-471.

19. A.A. El-Hadi, S.A. El-Nour, A. Hammad, Z. Kamel, M. Anwar. Optimization of cultural and nutritional conditions for carboxymethyl cellulase production by Aspergillus hortai, J. Rad. Res. Appl. Sci., 7 (2014) 2328.

20. T.V. Ojumu, B.V. Solomon, E. Betiku, S.K. Layokun, B. Amigun. Cellulase production by Aspergillus flavus Linn isolate NSPR 101 fermented in saw dust, bagasse and cornco, Afr. J. Biotechnol., 2 (2003) 150-152.

21. M. Irfan, Q. Syed, M. Gulsher, S. Abbas, M. Nadeem, S. Baig. Pretreatment of corncobs for the production of hydrolytic enzymes from Aspergillus niger-IR01, Int. J. Agro. Vet. Med. Sci., 4 (2010) 81-87.

22. M. Shahriarinour, M.N.A. Wahab, R. Mohamad, S. Mustafa, A.B. Ariff. Effect of medium composition and cultural condition on cellulase production by Aspergillus terreus, Afr. J, Biotechnol., 10 (2011) 7459-7467.

23. Z. Wen, W. Liao, S. Chen. Production of cellulase/ $\beta$ glucosidase by the mixed fungi culture Trichoderma reesei and Aspergillus phoenicis on dairy manure, Proc. Biochem., 40 (2005) 3087-3094. 
